\title{
EFFECT OF IRRIGATION MANAGEMENT ON CROP PRODUCTION FOR A DROUGHT-TOLERANT GENOTYPE OF BARLEY \\ Hokam, E. M. ${ }^{a}$ and I. H. El-Sheikh ${ }^{b}$ \\ a Soil and Water Dept., Faculty of Agriculture, Suez-Canal Uni., Egypt \\ b Agricultural Engineering Dept., Faculty of Agriculture, Suez-Canal Uni., Egyp
}

\begin{abstract}
The effect of sprinkler irrigation management on barley yield, soil moisture distribution and water use efficiency was studied under field conditions. A field experiment was conducted in 2005/2006 growing season in sandy loam soil, at WadiiGhepeen (Bani-Waleid Governorate, Libya),. A drought-tolerant genotype of barley (Hordeum vulgare L.: AKSAD 67) was irrigated by semi-portable sprinkler irrigation system with a local well-water (electrical conductivity of $2.7 \mathrm{dS} \mathrm{m}^{-1}$ ). The experiment included two factors: The frist factor was two levels of sprinkler distance: 12 and $6 \mathrm{~m}$, and the second factor was two levels of working hours: 2 and $3 \mathrm{~h}$. The control treatment was that recomended in the region (i. e. $12 \mathrm{~m}$ sprinkler distance and 5 working hours). So, the experiment consisted of five treatments, namely: $12 \mathrm{~m} \times 3 \mathrm{~h}$.; $6 \mathrm{~m} \times 3$ h.; $12 \mathrm{~m} \times 2$ h.; $6 \mathrm{~m} \times 2 \mathrm{~h}$. and $12 \mathrm{~m} \times 5$ h., labeled as A, B, C, D and Co, respectively.

To evaluate the performance of the sprinkler system and yield response to different treatments, many field measurements were achieved: local rainfall; sprinkler discharge (under working pressure of 2 bar); uniformity coefficient; total dry matter ; grain yield and water use efficiency. Also, change of soil moisture contents; seed germination percent and crude protin- were determined.

The main results can be summarized as follows: in general, the results indicated that both total dry and grain yields were increased as irrigation water amount decreased. The lowest water ammount was consumed under $\mathrm{C}$ treatment, therefore, appeared the highest water use efficiency.The statistic analsys shown that, there was no significant effect between sprinkler distances, while significant and high significant effect were found in both working hours and the interaction of sprinkler distance and working hours, respectively.

The results indicate that maximum uniformity coefficient was found under 6 $m$ treatments (i. e. B and D treatments). Germination test showed that, there was no observed effect as difference among all treatments. Following of soil moisture changes after irrigation, indicated that, it is not necessary to bring up soil moisture content to $100 \%$ of soil field capacity, while $50 \%$ of soil field capacity was found to be optimum amount for high yield production. Such irrigation water quality can be safely used, where the precipitation can prevents salt accumulation hazard.
\end{abstract}

Keywords: Sprinkler irrigation; Barley; Water use efficiency; Soil moisture distribustion

\section{INTRODUCTION}

Barley is an important food crop for irrigated regions in the world. Its growth and production may be limited by the applied amount of irrigation water. Both over-irrigation and under-irrigation has a significant effect either on yield quantity or quality. Fox et al. (2006) reported that, the genetic effect 
on grain size of barley was greater than environmental effect despite some sites suffering terminal moisture stress. By partitioning all variance components, and thereby having more robust estimates of genetic differences, plant breeders can have greater confidence in selecting barley genotypes which maintaines a large stable grain size across a range of environmentals. In this investigation a drought resistance genotype of barley (i. e. AKSAD 67) has been cultivated to study its responce to different irrigation managements. Thomson, et al. (1993) studied the morphological characteristics and chemical composition of barley straw fractions from several genotypes over a range of watering levels. They found that, the nutritive value of cereal straws from different genotypes are often complicated by the difference in plant height which is affected by genotype and the amount of rainfall. The range of water levels was obtained by using sprinklers to apply various levels of water in addition to normal rainfall. On the other hand, Sahnoune et al. (2004) found that the effect of low and moderate water deficit $(75 \%$ and $50 \%$ of soil field capacity) was slight, while the impact of severe water treatment (25\% of soil field capacity) was strongly marked on seminal root length and root-to-shoot dry matters' ratio.

As reported by Jamieson et al. (1995), final biomass was sensitive to drought timing and, in particular, was more sensitive to maximum potential soil moisture deficit for the early than the later drought treatments. Similar results have been found by Macnicol et al. (2002), who studied the effect of heat and water stresses on barley plants. The results showed that, the water stress at mid grain-fill led to decreased grain and increased malt extract.

The effect of supplemental irrigation and irrigation practices on soil water storage and barley crop yield were studied by Abu-Awwad (1998). The obtained results showed that, the differences in stored water had a significant effect on grain and straw yields of barley. The improvement is coming from the increased water storage associated with furrows. He recommended, since irrigation water is very limited if available, farmers are encouraged to form such furrows for reducing runoff from rainfall thereby increasing the amount of water available for forage and field crop production. In the current study, the amount of the local rainfall has been measured in the field, to detect the contribution of rainfall in irrigation water requirements.

The effect of salinity on barley was investigated by Hussain et al. (1997), whos studied the effect of saline water on growth parameters of six barley (Hordeum vulgare L.) cultivars in a pot experiment. Their results showed that, growth parameters decreased with irrigation water having EC of $9.26 \mathrm{dS} \mathrm{m} \mathrm{m}^{-1}$. Plant height and total number of plant tillers were decreased significantly with increasing irrigation-water salinity. Green matter and dry matter yields were decreased significantly with increasing irrigation water salinity. In conclusion, they found a lot of potential for a reasonable production of barley as forage crop with irrigation water having salinity up to $9.26 \mathrm{dS} \mathrm{m}^{-1}$ provided $15 \%$ extra water above crop-water requirement is applied as leaching requirements to control soil salinity. Well irrigation water used in this study had electrical conductivity of $2.7 \mathrm{dS} / \mathrm{m}$, therefore, such effects and problems can be avoided, but salt accumulation in soil was expected. According to Hoffman and Jobes (1983), the barley irrigated each 
day with small quantities of water have an electrical conductivity of $2.3 \mathrm{dS} \mathrm{m}$

1 , could be grown successfully.

The effect of sprinkler irrigation uniformity on crop yield is an important consideration for the design of sprinkler irrigation system. A model that relates yield response to evapotranspiration deficits at special growth stages to evaluate the impacts of uniformity on crop yield can be developed from a crop water production function. A simulation results of the model, which designed by $\mathrm{Li}$ (1998) showed that crop yield was increased with increasing uniformity. He found that, the optimum irrigation amount depends on irrigation uniformity and on economic factors, decreasing with the uniformity but increasing with the ratio of product price to water cost. The optimum uniformity was increased with an increase of irrigation amount expressed by a ratio between gross and required irrigation amount, but approximated $90 \%$ when the ratio exceeded 0.85 . The results obtained from the field experiments, demonstrated that, the relationship between spatial distribution of soil moisture and sprinkler application uniformity, where the water in the soil was more uniformity distributed than that measured for the application at the soil surface.

The areal distributions of soil water content under varying uniformities of sprinkler water application were observed on two different soil types. To quantify the relationship between the subsurface distribution of soil moisture and water application on the ground surface, field experimental results showed evidence of the importance of redistribution of the unevenly applied surface water. The water within the soil is more uniformly distributed than that applied through a sprinkler irrigation system. The extent of water redistribution within the soil profile depends mainly on the uniformity of initial soil water content and the total applied water, Li and Kawano (1996).

According to Li and Rao (2002), the determination of target uniformity for sprinkler irrigation system should consider the impacts of nonuniformity of water and fertilizers on crop yield. In their field experiment, irrigation water and fertilizers were applied through a solid set sprinkler system. The results showed that the uniformity of fertilizer applied was increased with sprinkler water uniformity. The obtained results demonstrated that the uniformity of sprinkler-applied water and fertilizers has insignificant effect on yield for the studied uniformity range. The current standard for sprinkler uniformity (for example, the target $\mathrm{CU}$ is equal to or higher than $75 \%$ in China) is high enough for obtaining a reasonable crop yield in dry sub-humid regions.

\section{MATERIALS AND METHODS}

\section{Field experiment layout}

A sprinkler Irrigation system (Semi-Portable System) was installed in a special farm of $2100 \mathrm{~m}^{2}$ at Bani Waleid Locality (semi-arid climate, in which

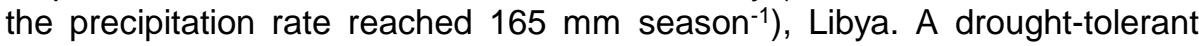
genotype of barley (Hordeum vulgare L.: AKSAD 67) was cultivated in sandy loam soil has electrical conductivity of (soil past extraction) of $1.6 \mathrm{dS} \mathrm{m}^{-1}$. The crop was irrigated by semi-portable sprinkler irrigation system with riser height of $0.7 \mathrm{~m}$. The water available for irrigation was local well water its 
salinity reaches $2.7 \mathrm{dS} \mathrm{m}^{-1}$. The working pressure during irrigations processes has been kept constant at 2 bar. The fertilization was done as followed in the region (i. e. $25 \mathrm{~kg} \mathrm{~N} \mathrm{ha}^{-1}$ ), and applied at the beginning of grain filling. Barley was seeded on November 1, 2005 and the crop was harvested on the first week of April, 2006.

The total experimental area was $2100 \mathrm{~m}^{2}$, divided into four different treatments, each one equaled to $525 \mathrm{~m}^{2}$. The treatments consisted of two different sprinkler spacings ( 6 and $12 \mathrm{~m}$ ) and two different working hours (2 and 3 hours). All treatments were labeled A, B, C and D, and expressed as following:

$A=12 \mathrm{~m}$ sprinkler space $X 3$ working hours

$\mathrm{B}=6 \mathrm{~m}$ sprinkler space $X 3$ working hours

$\mathrm{C}=12 \mathrm{~m}$ sprinkler space $\mathrm{X} 2$ working hours

$\mathrm{D}=6 \mathrm{~m}$ sprinkler space $\mathrm{X} 2$ working hours

The actual irrigation practice applied in the field (i. e. recommended in the region) was considered as the control treatment: $12 \mathrm{~m}$ sprinkler space $X 5$ working hours, and labled as Co.

Some measurements for the soil and irrigation system have been achieved either in the filed or in laboratory, as shown in table 1.

Table 1: Measurements achieved for the soil and irrigation system.

\begin{tabular}{|l|l|}
\hline Soil measurements (in upper $\mathbf{3 0} \mathbf{~ c m}$ ) & \multicolumn{1}{|c|}{ Irrigation system measurements } \\
\hline Soil bulk density, $1.57 \mathrm{~g} \mathrm{~cm}^{-3}$ & $\begin{array}{l}\text { Uniformity Coefficient of Christian } \\
\text { (catch cans } 2 \mathrm{~m} \text { separated) }\end{array}$ \\
\hline Soil field capacity, $31.9 \%$ volumetric & Sprinkler flow rate, $0.7 \mathrm{~m}^{3} \mathrm{~h}^{-1}$ \\
\hline $\begin{array}{l}\text { Saturation hydraulic conductivity, } 0.65 \\
\mathrm{~m} \mathrm{~d}^{-1}\end{array}$ & Working pressure, 2 bar \\
\hline $\begin{array}{l}\text { Soil texture, sandy loam: } 73 \% \text { sand, } 12 \\
\% \text { silt and } 15 \% \text { clay }\end{array}$ & $\begin{array}{l}\text { Diameter of wetting cycle was } 14 \mathrm{~m} \text {, in } \\
\text { average }\end{array}$ \\
\hline
\end{tabular}

Total dry matter, grain yield, weight of 1000 grains, germination percent and nitrogen content in grains have been used to evaluate the performance of the different irrigation managements. The statistical analysis for total dry yield and grain yield was performed based on split plot design, in which the control treatment (as a recommended practice in the region) was associated with both sprinkler distances.

\section{RESULTS AND DISCUSSION}

The irrigation network could be evaluated through some parameters, namley: Applied water amounts; soil moisture distribution; uniformity coefficient; water use efficiency; total dry yield; weight of 1000 grains; grain yield and germination test.

\section{Applied irrigation water and water use efficiency}

Amount of irrigation water for each treatment was estimated based on nozzle discharge, working hours, number of irrigations and wetted diameter. The results listed in Table 2 shown that excess irrigation water was recorded at $B$ treatment $\left(2475 \mathrm{~m}^{3}\right.$ water ha-1 season-1 resulted in $4905 \mathrm{~kg}^{-1}$ ha-1 total dry yield). The lowest amount was found at $C$ treatment $\left(800 \mathrm{~m}^{3}\right.$ water ha-1 resulted in $6062 \mathrm{~kg} \mathrm{ha}^{-1}$ total dry yield). 
Table 2: Applied water amount, AWA in $\mathrm{m}^{3} \mathrm{ha}^{-1}$; total dry yield, TDY in $\mathrm{kg} \mathrm{ha}^{-1}$; grain yield, GY in $\mathrm{kg} \mathrm{ha}^{-1}$ and water use efficiency, WUE in $\mathrm{kg} \mathrm{m}^{-3}$.

\begin{tabular}{|c|c|c|c|c|c|}
\hline Treatments & AWA & TDY & GY & $\begin{array}{c}\text { WUE of } \\
\text { TDY }\end{array}$ & $\begin{array}{c}\text { WUE of } \\
\text { GY }\end{array}$ \\
\hline A & 1200 & 5373 & 2470 & 4.48 & 2.00 \\
\hline B & 2475 & 4905 & 1647 & 2.00 & 0.70 \\
\hline C & 800 & 6062 & 2427 & 7.60 & 3.00 \\
\hline D & 1650 & 8394 & 3250 & 5.10 & 2.00 \\
\hline Co & 2000 & 3306 & 1452 & 1.65 & 0.73 \\
\hline
\end{tabular}

In general, under $C$ treatment comprative to $B$ treatment, $1675 \mathrm{~m}^{3}$ of irrigation water can be saved from one hectar each season, in spite of both total dry yield and grain yield were more at $C$ treatment than $B$ treatment. Water use efficiency, WUE, was calculated for both total dry yield and grain yield as shown in table 2. The obtained data indicated that, the highest WUE was found at $C$ treatment, 7.6 and $3.0 \mathrm{~kg} \mathrm{ha}^{-1}$ for both total dry yield and grain yield, respectively. On the other hand, the lowest WUE value was found at Co treatment, 1.65 and 0.73 for total dry yield and grain yield, respectively. According to these results, the irrigation managements could be recommended based on WUE values as following: $C(12 \mathrm{mX} 2 \mathrm{~h})>\mathrm{D}(6 \mathrm{mX}$ $2 \mathrm{~h})>\mathrm{A}(12 \mathrm{~m} \times 3 \mathrm{~h})>\mathrm{B}(6 \mathrm{~m} \times 3 \mathrm{~h})>$ Co $(12 \mathrm{~m} \times 5 \mathrm{~h})$.

\section{Total dry yield and grain yield}

Data listed in table 2 shown that total dry yield ranged from $8394 \mathrm{~kg}$ $\mathrm{ha}^{-1}$ (D treatment) to $3306 \mathrm{~kg} \mathrm{ha}^{-1}$ (Co treatment). The total dry yield for all treatment were in order of $\mathrm{D}>\mathrm{C}>\mathrm{A}>\mathrm{B}>\mathrm{Co}$. Likewise, results of grain yield ranged from $3250 \mathrm{~kg} \mathrm{ha}^{-1}$ to $1452 \mathrm{~kg} \mathrm{ha}^{-1}$ at $\mathrm{D}$ and Co treatments, respectively. Grain yield values for all treatments were in a similar order as following: D > A > C > B > Co. Generally, the higher applied water amount the smaller grain yield and total dry yield. These results indicated that the variation in applied water amounts had a great effect on both grain and total dry yield, a similar results were found by Thomson et al. (1993) and Abu Awaad (1998).

Table 3 gives the results of statistic analysis for all treatments. The results emphasized some different management treatments caused significant responses of the investigated barley genotype for both total dry yield and grain yield. Working hours and sprinkler distance interaction had high significant influence on both measured variables, while working hours treatment had a significant effect on both variable. On the other hand, sprinkler distance treatments were not significant for both variables, where the results show that the variation in sprinkler distance under the same working hours had no significant effect on the measured variables. From Table 3, the studied working hours and sprinkler distances interaction can be ranked according to their significance as following: $a>b>c$. 
Table 3: Performance of barley genotpye (AKSAD 67) for total dry yield and grain yield

\begin{tabular}{|c|c|c|c|c|c|c|c|c|}
\hline \multicolumn{5}{|c|}{ Total dry yield, $\mathrm{kg} \mathrm{ha}^{-1}$} & \multicolumn{4}{|c|}{ Grain yield, kg ha-1 } \\
\hline \multirow{2}{*}{$\begin{array}{l}\text { Sprinkler } \\
\text { Distance }\end{array}$} & \multicolumn{3}{|c|}{\begin{tabular}{|l|} 
Working hours \\
\end{tabular}} & \multirow[t]{2}{*}{ Main } & \multicolumn{3}{|c|}{ Working hours } & \multirow[t]{2}{*}{ Main } \\
\hline & $5 \mathrm{~h}$ & $\mathbf{3 h}$ & $2 \mathrm{~h}$ & & $5 \mathrm{~h}$ & $3 \mathrm{~h}$ & $2 \mathrm{~h}$ & \\
\hline $12 \mathrm{~m}$ & 3306 & 5373 & 6062 & 4914 & 1452 & 2470 & 2427 & 2116 \\
\hline $6 \mathrm{~m}$ & 3306 & 4905 & 8394 & 5535 & 1452 & 1647 & 3250 & 2116 \\
\hline Main & $3306 \mathrm{a}$ & $5139 \mathrm{~b}$ & $7228 \mathrm{c}$ & 5225 & \multicolumn{2}{|c|}{1452 a|2059 b } & $2839 \mathrm{c}$ & 2116 \\
\hline & \multicolumn{4}{|c|}{$\begin{array}{l}\text { L. S. D. distance }=\text { NS } \\
\text { L. S. D. working hours }=751.1 \\
\text { L. S. D. Distance } \times \text { working hours }= \\
1064.2\end{array}$} & \multicolumn{4}{|c|}{$\begin{array}{l}\text { L. S. D. distance }=\text { NS } \\
\text { L. S. D. working hours }=200.9 \\
\text { L. S. D. Distance } \times \text { working hours }= \\
1284.7\end{array}$} \\
\hline
\end{tabular}

\section{Weight of $\mathbf{1 0 0 0}$ grain, germination test and crude protein}

Weight of 1000 grain, germination test and crude protein $\%$ are listed in Table 4. The data show, that the lowest weight of 1000 grain (i. e. $28.3 \mathrm{~g}$ ) was found at Co treatment. Such trend was also recorded for total dry yield and grain yield listed in Table 2 . These results may be explained by the relative low uniformity coefficient at this treatment, in addition to excessive application of irrigation water. Data of germination test revealed that physiological property may did not judge by water stress. The obtained data show that germination percent values were closed each to other although the observed variation among the applied water amounts. For all treatments the values ranged from $90 \%$ to $99 \%$ at $A$ and $D$ treatments, respectivelty. These results are agree with that found by Fox et al. (2006), they reported that genetic effect on grain size was greater than environmental effects despite some sites suffering moisture stress.

Table 4: Weight of 1000 grain in g; germination test in \% and crude protein in \%.

\begin{tabular}{|c|c|c|c|c|c|}
\hline \multirow{2}{*}{ Parameters } & \multicolumn{5}{|c|}{ Treatments } \\
\cline { 2 - 6 } & A & B & C & D & Co \\
\hline Weight of 1000 grain & 38.3 & 40.7 & 36.7 & 36.7 & 28.3 \\
\hline Germination test & 99 & 95 & 94 & 90 & 96 \\
\hline Crude protein & 7.6 & 7.4 & 7.4 & 8.6 & 6.3 \\
\hline
\end{tabular}

The crude protein percent was calculated according to Rau and Johnson (1999), where nitrogen percent was multiplied by 5.7. The obtained data showed that excess irrigation water did not increase the quality of grain, the lowest value (i. e. $6.3 \%$ ) was found at Co treatment that received 2000 $\mathrm{m}^{3}$ ha $^{-1}$ water. On the other hand, the relative high values at $A, C$ and $D$ tratments, lead to conclusion that, for quality point of view relatively more water stress seems to be favourable.

\section{Soil moisture distribution}

Monitoring the change in soil water contents was done in upper 30 $\mathrm{cm}$ of soil profile (two months before harvest), where plant roots are diffused. Soil samples were collected just through the next ten days after irrigation, and 
the moisture content was gravemetric determined. Figure 1 illustrates the change in soil water contents for during the ten days period. Due to the differences in sprinkler distances, therefore, different applied water amounts, changes in soil moisture distribution becam clear. It is important to note that, the first value of soil water content (i. e. one day after irrigation) at $B$ and $D$ treatments was close to soil field capacity ( $31.9 \%$, lab. determined), reached $32.5 \%$ and $29.5 \%$ for B and D treatments, respectively, Figure 1 . The results indicated that, the difference between sprinkler distances may had the main effect on soil moisture distribution although the applied water amounts varied strongly from $1650 \mathrm{~m}^{3} \mathrm{ha}^{-1}$ to $2475 \mathrm{~m}^{3} \mathrm{ha}^{-1}$ for $D$ and $B$ treatments, respectively. On the other hand, soil moisture contents at the sam time reached $17.5 \%$ and $14 \%$ (i. e. about $50 \%$ of soil field capacity), at A and C treatments, respectively. So, under such field conditions the irrigation management can be achieved to keep the root zone wetted up to $50 \%$ of soil field capacity. A similar results was reported by Sahnoune et al. (2004), they stated that the impact of severe water treatment $(25 \%$ of soil field capacity) was strongly marked on barley growing, while the effect of low and moderate water deficit $(75 \%$ and $50 \%$ of soil field capacity) was slight.

The irrigation with such well water (i. e. $2.7 \mathrm{dS} \mathrm{m}^{-1}$ ) should be lead to larger salt accumulation in the root zone. Finally determination of soil salinty for all treatments indicated that soil salinity in the root zone, $30 \mathrm{~cm}$ depth, was decreased from $1.5 \mathrm{dS} \mathrm{m}^{-1}$ at the beginning of season to $0.6 \mathrm{dS} \mathrm{m}^{-1}$ at the end. This result may be explained because leaching effect resulted from the relative high precipitation (i. e. $165 \mathrm{~mm}$ season-1) during the grwing season. Evidently, this water quality can be used safely for irrigation under such field conditions without salinity hazard.

\section{Uniformity coefficient}

Typically, the higher the distance between sprinklers the smaller the water depth between sprinklers, therefore, the smaller water quantity stored in soil with poor wetting pattern. To insssure optimum uniformity coefficienty, $\mathrm{UC}$, is one of the most important factor for such aim. Uniformity coefficient of Cherestian, UCC, was used to estimate the uniformity coefficienty of the irrigation system for both $6 \mathrm{~m}$ and $12 \mathrm{~m}$ distances with discharge rate of 0.7 $\mathrm{m}^{3} \mathrm{~h}^{-1}$ and working pressure of 2 bar. The obtained results indicated that maximum uniformity $(92.7 \%)$ can be found at $6 \mathrm{~m}$ treatment, while reached $78.6 \%$ under $12 \mathrm{~m}$ treatment. As shown in figure 1, the high water content closed to soil field capacity at $D$ treatment may be related to its maximum uniformity ceofficient. Likewise and as reported by Li (1998), crop yield and water use efficiency increased with increasing uniformity ceofficient. The results shown that water contents within the soil was uniformity distributed either at UC of $92.7 \%$ or $78.6 \%$. According to Li and Kawano (1996) and Li and Rao (2002), both high values of UC may be resulted from a high uniformity of initial soil water contents. 
A treatment

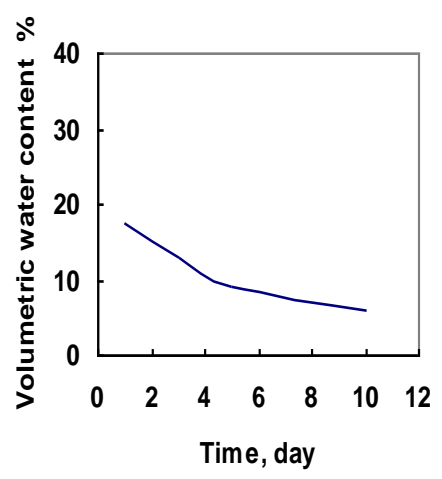

C treatment

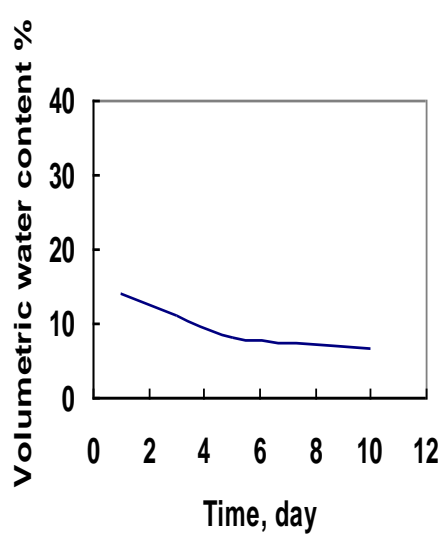

B treatment

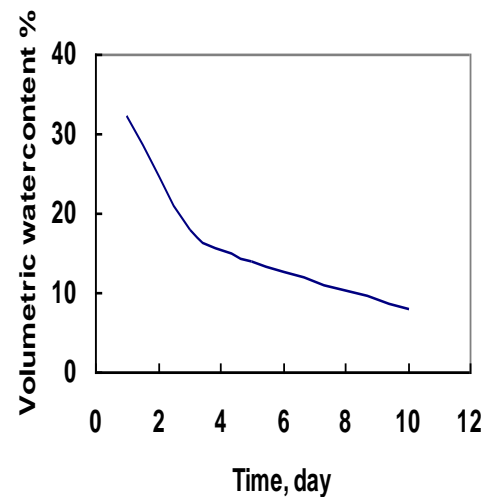

D treatment

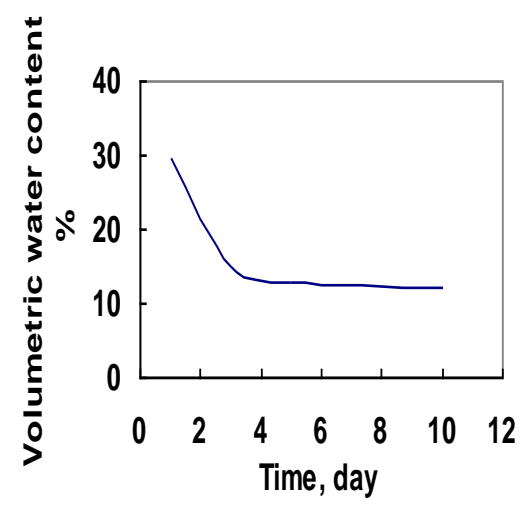

Figure 1: Soil moisture distribution at $30 \mathrm{~cm}$ soil depth 10066 


\section{Conclusion}

Sprinkler irrigation management affected the total dry yield; grain yield uniformity coefficient and water use efficiency. Under the different irrigation treatments, applied water amounts ranged from $800 \mathrm{~m}^{3} \mathrm{ha}^{-1}$ to 2475 $\mathrm{m}^{3} \mathrm{ha}^{-1}$, resulted in total dry yield of $6062 \mathrm{~kg} \mathrm{ha}^{-1}$ to $4950 \mathrm{~kg} \mathrm{ha}^{-1}$, respectively. So, for high water use efficiency it is not necessary soil water content at root zone to $100 \%$ of soil field capacity, as water content of $50 \%$ of soil field capacity seemed to be satisfied. The sprinkler distance of $6 \mathrm{~m}$ was associated with high applied water amount, high uniformity coefficient and high soil water content.

Drought tolerant barley genotype (AKSAD 67) seems to be stable across a range of different irrigation managements. Furthermore, water use efficiency was enhanced under water stress conditions (i. e. $800 \mathrm{~m}^{3} \mathrm{ha}^{-1}$ ).

Such quality of applied well-water $\left(2.7 \mathrm{dS} \mathrm{m}^{-1}\right)$ can be used safely for irrigation without salinity hazard; because of failed precipitation can prevents salt accumulation in the upper part of soil.

\section{ACKNOWLEDGEMENTS}

Authors would like to acknowledge the 7 October University in Libya for providing facilities and Prof. Dr. Abdel-Mmouttelb, H. from Suez-Canal University for his advice.

\section{REFERENCES}

Abu Awwad, A.M. 1998. Irrigation management in arid areas affected by surface crust. Agricultural Water Management, Volume 38, Issue 1, pages $21-32$.

Fox, G.P.; A. Kelly; D. Poulsen; A. Inkerman and R. Heary, 2006. Selecting for increased barley grain size. Journal of Creal Science, Volume 43, Issue 2, March 2006. $198-208$.

Hoffman, G. and J. Jobes, 1983. Leaching requirement for salinity control III. Barley, cowpea, and celery. Agricultural Water Management, Volume 6, Issue 1: March 1983, 1-14.

Hussain, G.; A.A. Al-Jaloud; S.A. Al-Shammafy; S. Karimulla and S.O. AlAswad, 1997. Effect of saline irrigation on germination and growth parameters of barley (Hordeum vulgare L.) in a pot experiment. Agriculutral Water Management, Volume 34, Issue 2, Pages 125-135.

Jamieson, P.D.; R. J. Martin; G.S. Francis and D.R. Wilsonm, 1995. Drought effects on biomass production and radiation-use efficiency in barley. Field crops Research, Volume 43, Issues 2 - 3, Pages 77 - 86 . 
$\mathrm{Li}, \mathrm{J}$. 1998. Modeling crop yield as affected by uniformty of sprinkler irrigation system. Agricultural Water Management, Volume 38, Issue 2: 135 146.

$\mathrm{Li}, \mathrm{J}$. and $\mathrm{H}$. Kawano, 1996. The distribution of soil moisture under sprinkler irrigation. Agricultural Water Management, Volume 32, Issue 1: 29 36.

$\mathrm{Li}$, J. and M. Rao, 2002. Field evaluation of crop yield as affected by nonuniformity of sprinkler applied water and fertilizers. Agricultural Water Management, Volume 59, Issue 1: 1 - 13.

Macnicol, P.K.; J.V. Jacobsen; M.M. Keys and I. M. Stuart, 2002. Effects of heat and water stress on malt quality and grain parameters of schooner barley grown in cabinets. Journal of Cereal Sceince. Volume18: Issue $1,61-68$.

Rau, W. and G. Johnson, 1999. Improving nitrogen use efficiency for cereal production. Agronomy journal, Volume 91: $357-363$.

Sahnoune, M.; A. Demha; M. Arimas; M. Meire;, K. Harch and O. Merah, 2004. Early water deficit effects on seminal roots morphology in barley. Comptes Rendus Biologies. Volume 327, Issue 4: April 2004, 389-398.

Thomson, F.E.; F. Herbert and S. Rihawi, 1993. Effects of genotype and simulated rainfall on the morphological characteristics, chemical composition and rumen degradation of the straw fractions of barley plants. Animal Feed Science and Technology, Volume 44, Issues 3-4: 191-208. 
تأثير إدارة الري بالرش علي إنتاج أحد أصناف الثعير المتحملة للجفاف

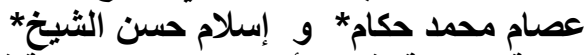

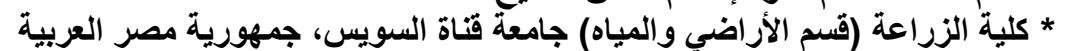
* كلية الزراعة (قسم الهندسةُ الزراعية) جامعة قناة السويس، جمهورية مصر العربية مصرية العربية

يهذف هذا البحث إلى تقييم أداء أحد أنظمة الري بالرش (ري بالرش النصف نقال بالر أس الدوارة)

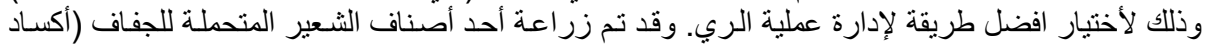



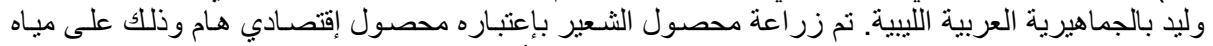

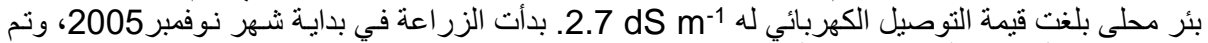

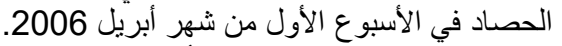

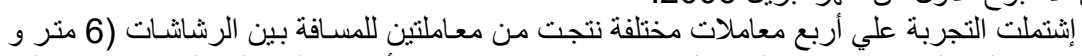

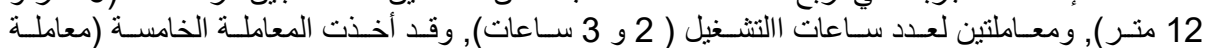

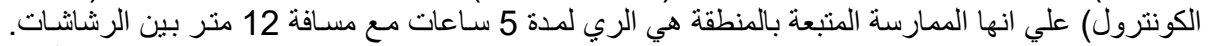

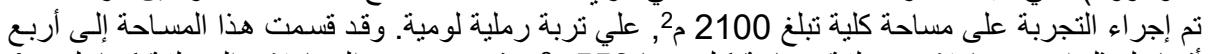

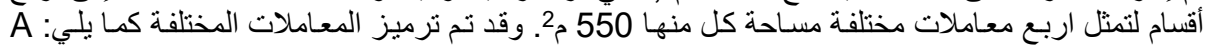

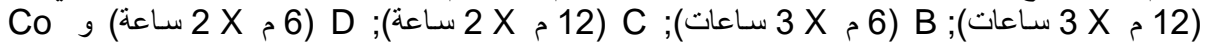

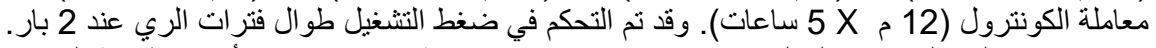

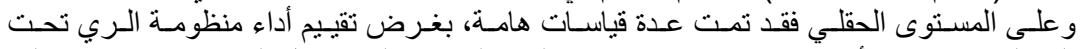

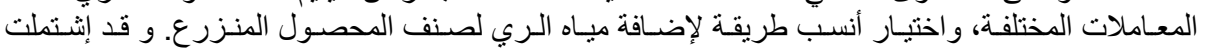

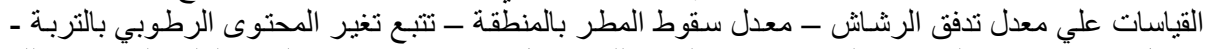

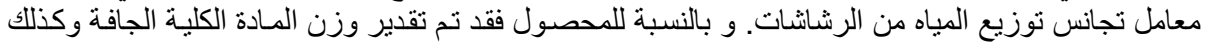

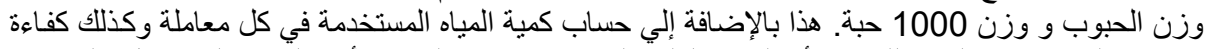

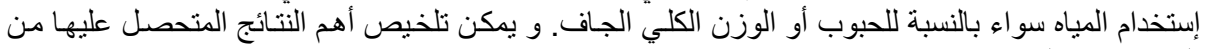

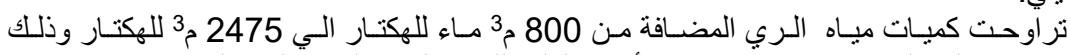

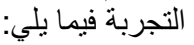

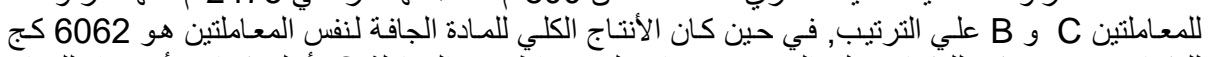

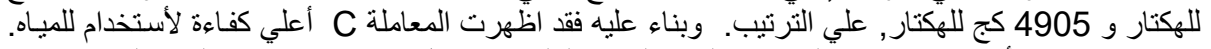

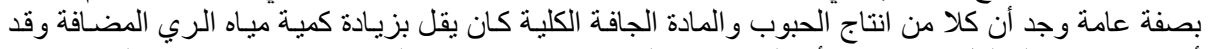

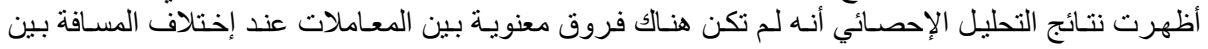

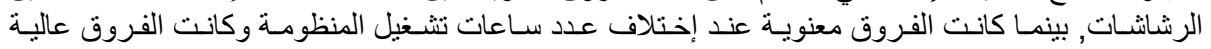

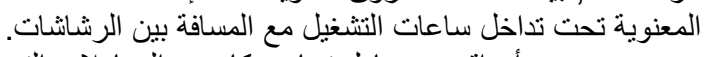

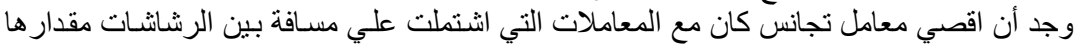

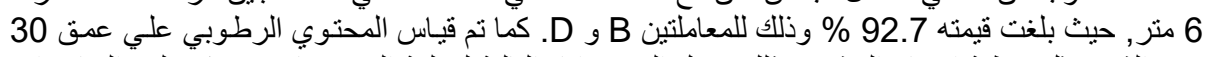

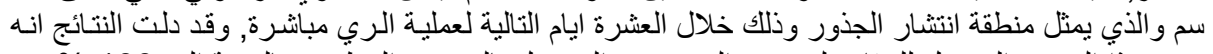

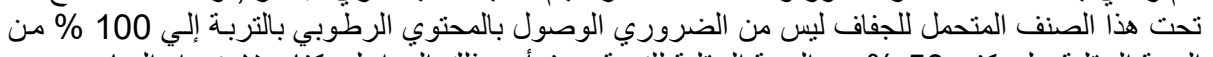

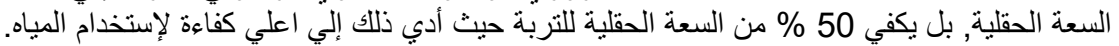

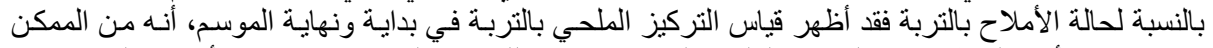

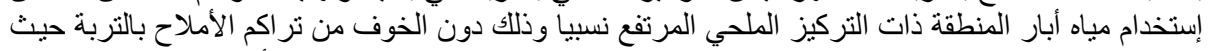
تودي كمية مياه المطر الساقطة بالمنطقة إلي إعادة غسيل التربة إلي مستوي امن من الأملاح. 
Hokam, E. M. and I. H. El-Sheikh

476247634764476547664767476847694770477147724773

477447754776

$\begin{array}{llllllllllll}4849 & 4850 & 4851 & 4852 & 4853 & 4854 & 4855 & 4856 & 4857 & 4858 & 4859 & 4860\end{array}$ 4861

$\begin{array}{llllllllllll}4873 & 4874 & 4875 & 4876 & 4877 & 4878 & 4879 & 4880 & 4881 & 4882 & 4883 & 4884\end{array}$ 4885

$\begin{array}{llllllllllll}4957 & 4958 & 4958 & 4958 & 49594960 & 4961 & 4962 & 4963 & 4964 & 4965 & 4966\end{array}$

$\begin{array}{llllllllllll}4967 & 4968 & 4969 & 4970 & 4971 & 4972 & 4973 & 4974 & 4975 & 4976 & 4977 & 4976\end{array}$ 4977497849794980

500550065007500850095010501150125013501450155016

5175

10070 